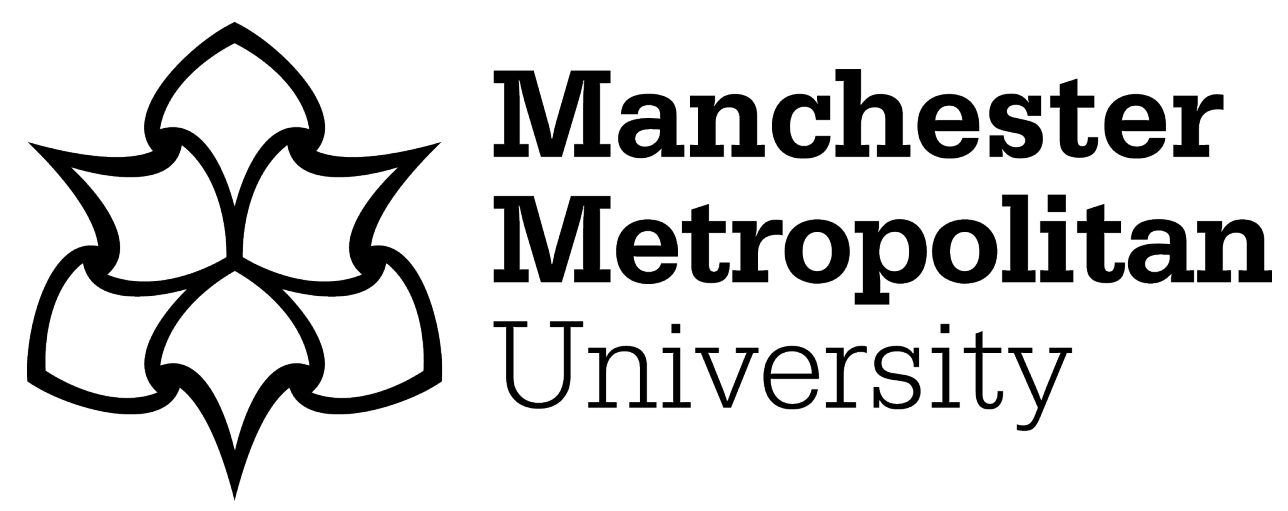

Syrrakos, D (2016) The Franco-German Alliance and its Role in the Process of European Monetary Integration: 1944-2010- Lessons for Today. Olsztyn Economic Journal, 11 (2). pp. 119-135. ISSN 1897-2721

Downloaded from: https://e-space.mmu.ac.uk/621883/

Version: Published Version

Publisher: University of Warmia and Mazury in Olsztyn

Please cite the published version 
OLSZTYN ECONOMIC JOURNAL

Abbrev.: Olszt. Econ. J., 2016, 11(2)

\title{
THE FRANCO-GERMAN ALLIANCE AND ITS ROLE IN THE PROCESS OF EUROPEAN MONETARY INTEGRATION, 1944-2010 - LESSONS FOR TODAY
}

\author{
Dimitrios Syrrakos \\ Accounting, Finance \& Economics Dept \\ Business \& Law Faculty \\ Manchester Metropolitan University Business School \\ e-mail: d.syrrakos@mmu.ac.uk
}

Ke y w or d s: Franco-German alliance, EU institutions, EMU debt crisis.

Abstract

The aim of this paper is to assess the evolution of the Franco-German alliance and the likely directions in its development. In particular, the question of whether the two countries' close relationship would survive the current economic and political obstacles is addressed. Emphasis is, placed on the way the alliance facilitated the creation of European Monetary Union. Therefore, the signing of the Treaty of Rome, the establishment of the European Monetary System, the creation of the Single European Act and the Maastricht Treaty are evaluated within this perspective. An underlying assumption throughout the analysis is that the prospects of the alliance and EMU will proceed in tandem. If the alliance continues to evolve successfully then the process of European economic integration will also progress, whereas if the two countries relations increasingly attenuate then the process of economic integration would at best stagnate. The main conclusion is that, following the Eurozone debt crisis the Franco-German alliance has been, replaced by "German Hegemony". This has rendered the main driving force of the European Union ineffective and as such has undermined the evolution of its institutions.

\section{SOJUSZ FRANCUSKO-NIEMIECKI I JEGO ROLA W PROCESIE EUROPEJSKIEJ INTEGRACJI WALUTOWEJ, 1944-2010 - WNIOSKI NA DZIŚ}

\author{
Dimitrios Syrrakos \\ Zakład Rachunkowości, Finansów i Ekonomii \\ Wydział Biznesu i Prawa \\ Uniwersytet Metropolitalny w Manchesterze, Szkoła Biznesu
}

Słow a klu c z ow e: sojusz francusko-niemiecki, instytucje UE, EMU kryzys zadłużenia. 
D. Syrrakos

\section{Abstrakt}

Celem pracy jest ocena ewolucji sojuszu francusko-niemieckiego i prawdopodobnych kierunków jego rozwoju. Szczególnie omówiono kwestię, czy dobre stosunki między obydwoma państwami przetrwają, mimo obecnych trudności gospodarczych i politycznych. Nacisk położono na sprawdzenie, w jakim stopniu zawarcie sojuszu przyczyniło się utworzenia europejskiej unii walutowej. Pod tym kątem oceniono podpisanie traktatu rzymskiego, utworzenie europejskiego systemu walutowego, zawarcie jednolitego aktu europejskiego i traktatu z Maastricht. Podstawowym założeniem całej analizy jest to, że rozwój sojuszu oraz europejskiego systemu monetarnego będą iść w parze. Jeśli sojusz z powodzeniem nadal się będzie rozwijać, to proces europejskiej integracji gospodarczej będzie również postępował, jeżeli jednak stosunki między dwoma wspomnianymi krajami się pogorszą, to proces integracji gospodarczej w najlepszym razie ulegnie stagnacji. Główny wniosek jest taki, że w następstwie kryzysu zadłużenia strefy euro sojusz francusko-niemiecki zastąpiono „niemiecka hegemonią". To spowodowało, że główna siła napędowa Unii Europejskiej stała się nieskuteczna i jako taka osłabiła rozwój tej instytucji.

\section{Introduction}

The "Great Recession" has irreversibly changed international monetary relations. The United States no longer enjoys a hegemonic position in international monetary arrangements whereas China has emerged as one of the world's most powerful economies. The UK and Japan are significantly weaker while Russia seeks to rebuild its status as a major international power. Other developing economies like Brazil and India are aiming to achieve similar international recognition while France and Germany are still trying to coordinate their policy responses within the European Monetary Union (EMU) framework. This unstable international balance of power places international monetary relations under immense strain. France and Germany are no exceptions. Despite the fact that the process of European monetary integration, leading to the creation of EMU on January 1, 1999, was, facilitated by the Franco-German alliance, the two countries interests are not necessarily convergent. The aim of this paper is to assess the evolution of the Franco-German alliance and the likely directions in its development. Focused effort is given on the way the development of the alliance's characteristics facilitated the establishment of the EMU.

The rest of the paper is organised as follows. In section 2 , the principal question of whether the success of the Franco-German alliance can be attributed to the converging economic interests or to the institutional approach adopted, is put in a wider context. In section 3, the Franco-German relations between 1944 and 1956 are assessed. Section 4 examines the building and the evolution of the Franco-German alliance from 1957 to 1975. Section 5 draws on the way the alliance facilitated the process of European monetary integration from 1976 to 1989. The collapse of the Eastern European Communist regimes and its impact on the alliance is evaluated in Section 6. Finally, in section 7 the main conclusion and lessons for today are presented. 


\section{The Franco-German alliance}

The history of Franco-German relations following WWII is characterised by initiatives that have shaped the European continent. The creation of the EMU alongside the European Central Bank (ECB) on January $1^{\text {st }}, 1999$ is an example. However, the two countries' relations over the last seventy years were not immune to conflict and most of its achievements were the outcome of tough, lengthy negotiations, which involved mutual compromises.

In evaluating the success of the Franco-German alliance the converging interests of France and Germany have received attention (GoODMAN 1992, Andrews 1993, Gross, Thygesen 1998, Henning 1998, McNamara 1998, MoRAVCSIK 1998). Others stress the importance of the Franco-German leadership model within the EU and the EMS (DE GraUwe 1990, GiavazzI, GiovaNNiNi 1989, FratianNi, von Hagen 1990a, b, ARROwSMith 1996). On the other hand, others emphasise geopolitical developments such as the collapse of Eastern European Communist regimes and the security implications for both France and Germany as the primary factor for the strengthening of the alliance in the last twenty-five years (GARRETT 1993, BAUN 1996, MAZZUCELLI 1997). Lastly, there are those that view the success of the Franco-German alliance, as reflecting the promotion of specific interest groups in both countries such as banks and financial institutions, epistemic communities or the European Commission (Dyson, Featherstone 1999, JABKo 1999, VERduN 1999).

These explanations make a significant input in the assessment of the Franco-German alliance and its role in establishing EMU. In this paper, an institutional approach is put forward to account for the success of the alliance in terms of facilitating the realisation of the EMU. It is argued that it was the institutions established, that strengthened the alliance and facilitated the realisation and evolution of the EMU. Four different periods are identified in terms of the alliance's internal balance, reflected in the establishment and evolution of new EU institutions.

The first period covers the years from 1944 to 1956. French-German relations in this period were formulated within the framework of a divided Europe and the reconstruction process in the aftermath of WWII. During the second period, from 1957 to 1976, the two countries relations rapidly improved and the countries' leaders laid the foundations for the Franco-German alliance. During the third period, from 1976 to 1990, there was a shift in the internal balance of the alliance towards West Germany due to its successful economic performance in the 1970s. The gradual adoption of the German anti-inflationary paradigm by France, led to Germany enjoying a leadership status in the alliance in the 1980s. The European Monetary System (EMS) and 
the dominant position of Deutschmark in it reflected this changing balance of power in the alliance. The fourth period, from 1990 to 2010, begins with the collapse of the Eastern European Communist regimes and the reunification of Germany. In the initial stages of this period, reunified Germany is weakened economically while France sought to restore its parity status in the alliance by committing Germany irrevocably to EMU. The completion of the Common Market with a single currency was not in line with German interests. However, Germany eventually accepted EMU participation in order to preserve its commitment to European integration, as long as EMU would not compromise the objective of price stability. The creation of the ECB was a compromise France conceded to, in order to secure the creation of EMU. Despite this compromise, the structure of ECB does not guarantee decisions coinciding with German interests. To that extent, EMU and the ECB reflect a changing internal balance in the Franco-German alliance in favour of France.

The "Great Recession" had a major impact on the alliance. The EU response to the EMU debt crisis in particular in Greece, Ireland, Portugal, Spain and Cyprus exposed the alliance to its weaknesses. The bailouts to the first three provided a short-term answer to the debt crisis. However, they did not resolve the long-term differences of the alliance and neither do they offer a way forward to EMU. The alliance's formation and evolution does not reflect permanently converging interests but institutions created in periods of converging interests that sustained EU in times of crises. The European Payment Union (EPU) in the first period was part of the overall reconstruction effort. The European Economic Community (EEC) and the Common Agricultural Policy (CAP) in the second period reflected the parity terms of the alliance. The EMS reflected the leading status of Germany, whereas EMU and the ECB reflect the challenging of this dominant German status by France. Institutions have therefore maintained the alliance even in periods of divergent interests such as the 1992-1993 EMS crisis. Next, an assessment of each of the four periods identified is presented.

\section{The Early Years: 1944-1956}

The end of WWII saw France and Germany in one of the most difficult situations they had ever been to. France was at the edge of financial collapse and political chaos. This dramatic situation was matched by a low morale and a massive Communist party with its prestigious resistance record. There were also a plethora of additional problems, involving colonial wars and social unrest. On the other side of the Rhine, things were even worse. The country was largely destroyed, its fate uncertain and its people devastated. Germany 
stood partitioned as it was, divided into four sectors, with eighteen million Germans under Soviet authority. It had no formal representation and its fate was lying in the hands of the occupying countries. Thus by 1945 both countries had nothing in common with the two powerful European nations of the early twentieth century.

Despite this immensely difficult environment, Germans were still determined to rebuild their country. However, recovery did not get under way up until 1948 when the currency reform, according to which ten old marks were replaced by one mark, took place. The outcome of the reform was spectacular. In 1948, production was increased by $50 \%$ and in 1949 production was once more increased by $25 \%$. During the course of the next year, the volume of foreign trade doubled, whereas in the next year it was increased by another $75 \%$. The efforts of the German authorities to rebuild the German economy were also boosted by the devaluations of the European currencies in 1949 against the dollar. The devaluation rates for West Germany, the Netherlands, Sweden and the UK together with the increase in the prices of the USA dollar, wholesale prices, the increase in the cost of living and the wage rates are presented in table-1. As it can be observed the Deutschmark was devalued by $20.6 \%$ in relation to the USA dollar. This was followed by an increase in wholesale prices by $70 \%$ in Germany, far higher than any other country in Table 1 , and an increase in the cost of living by $13 \%$. Nominal wages increased by a staggering $54 \%$.

Currency Devaluations and increase in prices by March 1952 in relation to 1948

\begin{tabular}{|l|c|c|c|c|c|}
\hline \multirow{2}{*}{ Countries } & $\begin{array}{c}\text { Percentage } \\
\text { rate of } \\
\text { devaluation } \\
(-)\end{array}$ & $\begin{array}{c}\text { Corresponding } \\
\text { increase in the } \\
\text { price of the US } \\
\text { dollar }(+)\end{array}$ & $\begin{array}{c}\text { Increase } \\
(+) \text { in } \\
\text { Wholesale } \\
\text { prices }\end{array}$ & $\begin{array}{c}\text { Increase } \\
(+) \text { in } \\
\text { cost of } \\
\text { living }\end{array}$ & $\begin{array}{c}\text { Increase } \\
(+) \text { in } \\
\text { Wage } \\
\text { rates }\end{array}$ \\
\hline United States & - & in $\%$ & in $\%$ & in \% & in \% \\
\hline West Germany & -20.6 & - & 8 & 11 & 25 \\
\hline Netherlands & -30.2 & 46 & 70 & 3 & 54 \\
\hline Sweden & -30.5 & 44 & 52 & 26 & 22 \\
\hline United Kingdom & -30.5 & 44 & 53 & 24 & 22 \\
\hline
\end{tabular}

Source: Bank for International Settlements, Twenty Second Annual Report (1952, p. 81).

On the other hand, reconstruction in France was based on the adoption of indicative planning. By the early 1950s, recovery was well under way and by 1954 industrial production was 50\% higher than in 1939. Unprecedented high growth rates made France the fastest growing economy in the world. Again, 
this recovery was facilitated by the devaluation of the French franc. The 1952 rates of devaluation for a selected group of countries, from their 1945 and 1949 benchmarks are presented in Table 2 . As it can be observed the rate of depreciation of the French franc equalled $22.1 \%$ and exceeded the $20.6 \%$ rate of the Deutschmark.

Table 2

Official exchange rates 1945-1952

\begin{tabular}{|l|c|c|c|c|c|}
\hline \multirow{2}{*}{ Countries } & \multicolumn{5}{|c|}{ U.S dollar middle rate } \\
\cline { 2 - 6 } & $\begin{array}{c}\text { 31st December } \\
1945\end{array}$ & $\begin{array}{c}15 \text { th September } \\
1949\end{array}$ & $\begin{array}{c}31 \text { st March } \\
1951\end{array}$ & $\begin{array}{c}\text { 31st March } \\
1952\end{array}$ & $\begin{array}{c}\text { \% change } \\
\text { 15 Sept. 1949 } \\
\text { to March } 1952\end{array}$ \\
\hline France & 119.1 & 272.495 & 350 & 349.95 & -22.1 \\
\hline West Germany & 10 & 3.33 & 4.2 & 4.2 & -20.6 \\
\hline Greece & 500 & 10.010 & 15.000 & 15.000 & -33 \\
\hline Ireland & 0.2481 & 0.2481 & 0.3571 & 0.3555 & -30.3 \\
\hline Italy & 100 & 575 & 624.85 & 624.88 & -8 \\
\hline Netherlands & 2.65 & 2.653 & 3.8 & 3.8 & -30.2 \\
\hline U.K. & 0.2481 & 0.2481 & 0.3571 & 0.3555 & -30.2 \\
\hline
\end{tabular}

Source: Bank for International Settlements, Twenty-Second Annual Report (1952, p. 133).

Indicative planning was based on five-year plans. These offered the element of stability in a period of political uncertainty and colonial wars. Full employment, steady increases in real wages together with high growth rates were the distinctive features of the French economy up to the 1960s (CRAFTS, TONIOLO 1996).

It was also during this period that the three non-Soviet sectors of occupied Germany emerged as a unified state. In 1952, the "new country" became a member of the European Coal and Steel Community. However, by that year, the situation in international relations had changed dramatically and the cold war determined international relations. The deteriorating relations between the USA and the USSR up to 1949 and the division of the world into the Western and the Eastern camps signalled a drastic change in the USA's foreign, military and economic policies.

The revision of the American policy resulted in the Marshall Plan (MP) in 1948 with the Foreign Assistance Act, granting the European Cooperation Administration (ECA) to take charge of the implementation of the program. France and West Germany were the two major beneficiaries of the Plan. Initially the aid targeted the improvement of basic needs such as food. Later on, the emphasis shifted to industrial reconstruction with machinery import- 
ation playing the dominant role. By 1950 , the aid had amounted to $\$ 11.5$ billion (YEAGER 1965).

The MP contributed immensely to the reconstruction of the Franc and West German economies. The recipient countries experienced an average of $40 \%$ increase in their industrial production during 1948-1952. The physical volume of exports more than doubled, the volume of imports increased by about one third and inflation rates had been, maintained at modest levels. In addition to these developments, France and West Germany had managed to restore their reserves, something that was accompanied by losses of the USA gold reserves. Gold reserves in Western Europe increased from $\$ 8.4$ billion at the end of 1949 to $\$ 17.2$ billion in 1956 . This partly reflected the impressive economic recovery in both countries throughout the 1950s (SOLOMON 1982).

In order for the MP to be effectively administered, the OEEC was established in 1948. Whilst the European countries were provided with sufficient dollar reserves to pay for imports from the USA, substantial deficits were building up in intra-European trade. In addition, trade in Europe was restricted by bilateral arrangements as each country was seeking to gain access to US dollars. The solution to these problems was provided by the creation of the EPU in 1950, paving the way to convertibility of the main European currencies by 1958 (Tew 1988, Molle 1997, Williams 1999, Dinan 1999).

\section{France and Germany in the European Community: 1957-1975}

In 1958, Charles De Gaulle assumed the French Presidency. De Gaulle perceived indicative planning as a means of facilitating the realisation of his vision, the lifting of his country to the status of a global power, participating in the international decision-making. This policy came to imply the engagement of France in developing nuclear weapons and its commitment to an integrated Europe. In this way France was presented as a credible military ally and thus as a suitable partner to Germany. This matched the existing potential for strengthening the Franco-German relations arising from the successful economic cooperation within the EPU and the Suez crisis in 1956. Indeed, in the late 1950s and early 1960s De Gaulle and Adenauer laid the foundations for the Franco-German alliance (SERFATy 1968, DoRMAel 1978, Solomon 1982).

However, the status quo established in Western Europe in the late 1940s started to show signs of disintegration in the 1960s. The engagement of the USA in the South East Asia provoked an unprecedented French attack on the American policy. This French offensive made the Americans seeking to improve their relation with West Germany. The end of the USA's monopoly over the protection of West Europe together with De Gaulle's intransigence in 
demanding an exclusive relationship with Germany placed German foreign policy in a very difficult position and senior German politicians were split into Gaullists and Atlanticists. Adenauer's conviction was that only the close cooperation between France and West Germany could facilitate the reunification of Germany. Chancellor Erhard did not accept President De Gaulle's invitation to form a closer alliance not because he intended to inflict a blow in the Franco-German relations, but because he was not prepared to go that far as to renounce the USA military protection (HILDEBRAND 1989).

It was the Berlin crisis in 1960-1961 that changed German perceptions of President De Gaulle. West Germans were deeply disappointed with the American response to the escalation of the crisis, which was limited to the condemnation of the Wall. However, the 1966 De Gaulle's visit in the USSR and the German doubts on whether France possessed the military capability to counter the Soviet nuclear arsenal implied that the time was not ripe for the launching of an even closer alliance between the two countries. Within this fragile policy framework President De Gaulle's decision to depart from the military section of NATO created more tensions.

In addition to these problems in the late 1960s, economic issues started to attract growing attention from the European policy makers. The inherent instability of the IMF system was pointed out as early as 1960 . The fact that the MP beneficiaries could not resort to the IMF resources, effectively implied that the American balance of payments was imposed as the main source of international liquidity. A deliberate policy to reduce the American deficit therefore would create a shortage of international liquidity. If on the other hand the USA government did nothing to cure the deterioration in its balance of payments, confidence in the dollar would weaken, as the ratio of US gold holdings to US liabilities would steadily decline (TRIFFIN 1961).

The reluctance of the American authorities to remedy the growing balance of payments deficit and disputes between France and the US undermined the system as it became evident in late 1967 when the British government devalued the pound by $14.3 \%$. This provided the excuse for President De Gaulle to reject the second British application for joining the EEC on the grounds of a weak UK economy. This put the German foreign policy once more under pressure.

The solution was provided by the ascent to power of Georges Pompidou. France adopted a less hostile policy towards NATO and the USA and it stopped opposing the British entry into the Community. This drastic change in the French foreign affairs came as a result of the German attitude during the Bonn Currency Conference in 1968. Germany having realised her relative economic strength, demanded that their national interests be respected at the expense of the interests of the deficit countries, which at the same time were her 
protectors against Communist threat. The same year the separation of the official from the private market of gold took place. As the creation of this two-tier system did not provide a solution soon after speculative attacks resumed as indicated by the devaluation of the franc in August 1969 by $11 \%$ and the revaluation of the mark later in the year (SOLOMON 1982, Gros, THYGESEN 1998).

These three realignments put pressure on the CAP. As a result, another means of maintaining the existing system of agricultural policy had to be, invented. The only solution could be, provided through the adoption of different price levels for the countries (GISCARD D'ESTAING 1994). In order for this system to be sustained, a complex system of Monetary Compensatory Amounts (MCA) was created. However, this system contradicted the Community's objectives and intended to be only a temporary one.

The efforts to reduce the growing USA balance of payments deficit led to the 1968 agreement concerning the creation of the Special Drawing Right (SDR) as a major source of international liquidity, following a debate between American and French authorities concerning the asymmetry of the system. The main motivation behind the introduction of the SDR was its potential contribution in reducing the role of the US dollar as an international reserve currency. However, the USA's global commitments in relation to the cold war and the maintenance of the existing status quo in the western alliance made the elimination of the USA deficit highly unlikely (WILLIAMS 1991). By 1969, it was evident that the EEC might have to design its own mechanism facilitating exchange rate coordination. The presentation of the Werner Plan in 1970s called for the creation of such a mechanism with the decision to establish a monetary union in the EEC within a decade. However, the Werner Plan assumed that its objectives would be met within the framework of the IMF system, as regardless of its malfunctioning, its collapse could not have been foreseen (SYRRAKOS 2010). When eventually the introduction of the SDR took place on January 1, 1970 it could not replace the dollar as the main reserve currency and thus ensure the viability on the IMF system. The inevitable result was the devaluation of dollar with the automatic suspension of its fixed price relation to gold in 1971, which led to the collapse of the IMF system in 1973.

The collapse of the IMF system implied that the Werner Plan's guidelines were, effectively, left aside. Within this framework, France and West Germany failed to agree on a common stance to the international monetary crisis. The situation deteriorated even further with the occurrence of the first oil shock in 1973/74. France did not wish to abandon its growth-orientated policies whereas Germany could not compromise its long-standing anti-inflationary record. However, Brandt's West Germany was a lot stronger than, Giscard D'Estaing's 
France, despite Pompidou's efforts aiming to boost growth. This was reflected with "Ostpolitik", a truly independent West German foreign policy.

\section{German Dominance: 1976-1989}

The international monetary turmoil of the 1970s leading to unilateral decision-making in exchange rate policies and the inability of the French and West German governments to adopt a common stance to the problems accelerated divergences in economic policies. Had the divergences persisted they would eventually undermine all early endeavours seeking to promote monetary integration (GROS, THYGESEN 1998). The initiative undertaken by the French and the German governments in 1978 to establish a European system of collectively managing monetary affairs was the way forward for the EEC.

However, the decision to create the EMS in 1978 was politically driven. In the late 1970s the relative economic decline of the USA in relation to Japan and West Germany, the converging economic and political interests of France and Germany and the fading war memories, provided the necessary impetus for both countries to raise jointly their objections to the policies adopted by the Carter Administration. This reflected the growing confidence of both France and West Germany. Given the general scepticism of the British officials towards the overall EMS effort, it was again the Franco-German consensus that gave the impetus for the promotion of monetary stability in the EEC (SUMNER, ZIS 1982, GEORGE 1996).

Indeed, the instability of the dollar during 1978 accelerated the acceptance of an economic and a political rationale for the need to stabilise intra-European exchange rates through the creation of an independent European exchange rate mechanism (UNGERER 1983, GROS, THYGESEN 1998). The creation of the EMS reflected the revival of the Franco-German alliance. After almost a decade both countries seemed determined in pursuing policies aiming to safeguard their common interests and as such lead the way for the Community as a whole.

The successful performance of the EMS during the 1980s implied that the Franco-German alliance entered a new period characterised by a series of initiatives whose outcome was highly successful. The Single European Act (1986) and the Delors Report (1989) were the most significant ones matched by an impressive EMS record. However, it was the decision of the French Socialist government in 1983 to embark upon an anti-inflationary policy that facilitated the success of these initiatives (VANTHOOR 1996, Cram 1997, Dinan 1999, SzASZ 1999, WaLlaCe, WALlaCe 2000). 
The Single European Act implied one more step towards monetary union, as it became apparent in June 1988 when the European Council formed an Expert Committee consisting of the Central Banks' governors with the aim to submit proposals concerning the realisation of EMU. The Delors Report on Economic and Monetary Union in the European Community contained specific proposals concerning the realisation of economic and monetary union in three stages. The most important proposal put forward by the Report was the need for the creation of a single European currency (DAVIDSON 1996, DiNAN 1999). No formal deadlines were set but it recommended that the first stage would start together with the full liberalisation of capital movements in July 1, 1990. A common monetary policy was to be assumed by the independent ECB (CRAWFORD 1996). However, short after the Report's publication, events that led to the collapse of the Communist regimes in Eastern Europe were under way, signalling the impending change in the "world order" (TsoukALIS 1996).

The reunification of Germany was thus seen as a sufficient reason for strengthening the Community as a whole, so as it would not alarm the rest of the Community members and in particular France. French officials were highly sceptical and feared that these events could undermine Germany's willingness to maintain its position in the Franco-German alliance, as Germany could seek to develop new political and economic ties with Eastern European countries, in particular Poland.

\section{An Attempt to Restore Parity: 1990-2010}

Helmut Kohl was aware of the fears associated with German unification across Europe. Thus, his initiatives aiming to promote further political integration in EU came soon after the unification of his country (DYSON, FEATHERSTONE 1999). Along the same lines, was the French desire for the establishment of a single currency into the early 1990s (SzASz 1999). In France, the launching of the EMU project was seen as acquiring leadership in the EU and the international sphere. French officials saw the engagement of Germany in an irreversible agreement concerning the launching of monetary union as the best way of aligning her demands with the needs of the Community (TSOUKALIS 1996, UNGERER 1997, SzASZ 1999).

On the other hand, Germany feared that such a development could lead to the erosion of monetary independence (TsOUKALIS 1996, SzASZ 1999, DiNAN 1999). Thus, Germany's consent had to be accompanied by the establishment of an independent central bank whose prime objective had to be the maintenance of price stability (PELKMANS 1997, HIX 1999). The acceptance of these proposals came as the French policy makers saw Central Bank independence 
as a sacrifice France had to make for the survival of the process of European integration, prepared the grounds for the signing of the Maastricht Treaty (BINI-SMAGHI et al. 1994, SZASZ 1999).

However, the exchange rate turbulence of June 92-July 93, raised questions as to whether the agreement signed in Maastricht will be implemented or not. At a time, it almost seemed that the Treaty was abandoned. Following the collapse of Communist regimes in Eastern Europe, it was as if the alliance existed only in words. This feeling of the impeding end of the two countries partnership gave rise to mounting criticism on the willingness of the European governments to proceed with the implementation of what was agreed in Maastricht. Given that the political commitment towards the fulfilment of the Maastricht criteria was questioned, so was the ability of the EMS to facilitate the realisation of the EMU, as the road to the EMU was itself inextricably dependent on this political commitment. The natural consequence of all this were the difficulties encountered by the system culminating in the 1992-1993 EMS crisis.

Yet, the EMS crisis managed to unleash new forces pertinent to the process of monetary integration, as by the end of 1994 it appeared to emerge more powerful than ever. This was the case, as the imperatives of the new era required the exercise of a unique, meaningful German foreign policy. Such a vision could not take shape in the absence of a military background. Germany could instead commit herself further towards an even more integrated Europe that could then assert its foreign policy autonomy. France was also lacking the economic capacity necessary for the formation of an independent French foreign policy. The two partners had realised that their alliance was too important to miss and as a result, confidence in the process leading to the EMU was boosted (COBHAM 1994, COLE 2001).

Indeed, from August 1993 to December 1998 member countries did not exploit the increased monetary independence afforded by the wider Exchange Rate Mechanism (ERM) bands as not a single country used them after the 92-93 crisis. The Franco-German alliance soon after the crisis resumed its potential and there was a resurgence of the political willingness to move towards the creation of the EMU as demonstrated by the decision of Austria, Finland and Sweden to apply for EU membership in 1994. Intra-EMS exchange rates returned within the narrow band rapidly, national inflation rates continued to converge and progress towards the implementation of the 1992 programme was maintained (SYRRAKOS 2010).

The successful outcome of this progress was the creation of EMU on January $1^{\text {st }}, 1999$ and the establishment of the ECB. Despite concerns relating to the viability of EMU, given the lack of progress towards a European Political Union, its evolution with the addition of eight more countries since its 
inception and its smooth functioning from 1999 to 2009 have pave the way to an even closer alliance between France and Germany. The diagnosis that EMU cannot be sustained as EU is not an Optimum Currency Area (OCA) and economic pressures would, sooner or later, lead to its collapse, or, the claim that EMU cannot endure without European Political Union seemed to have lost their validity in the light of its successful performance up to 2009 (EICHENGREEN, WyLPOSZ 2016).

Even the "Great Recession" was initially perceived as a strictly "AngloSaxon" phenomenon attributed to the mismanagement of the USA and the UK financial systems, that would have a limited impact on France and Germany. Only when the full scale of the crisis unfolded itself and its international implications became apparent, the French and German governments responded to it. However, this response was limited to both countries' domestic economies with emphasis placed on fiscal expansion and financial support to French and German financial institutions and industries. This created a leadership gap at a Eurozone and EU level, and the replacement of the Franco-German alliance by "German Hegemony" from 2011 to present. This took place on the background of French deficits in the bilateral balance of trade between the two countries, as depicted in figure 1 that covers the period from 2001 to 2010. As it can be observed in figure 1, following the Great Recession France accumulated a trade deficit in excess of $€ 23.604$ million ( $€ 23.6$ billion) with Germany. This change in the alliance's internal balance in favour of Germany, allowed the country to gain the upper hand in the policies put forward by the EU, in response to the EU debt crisis from 2010 to 2015.

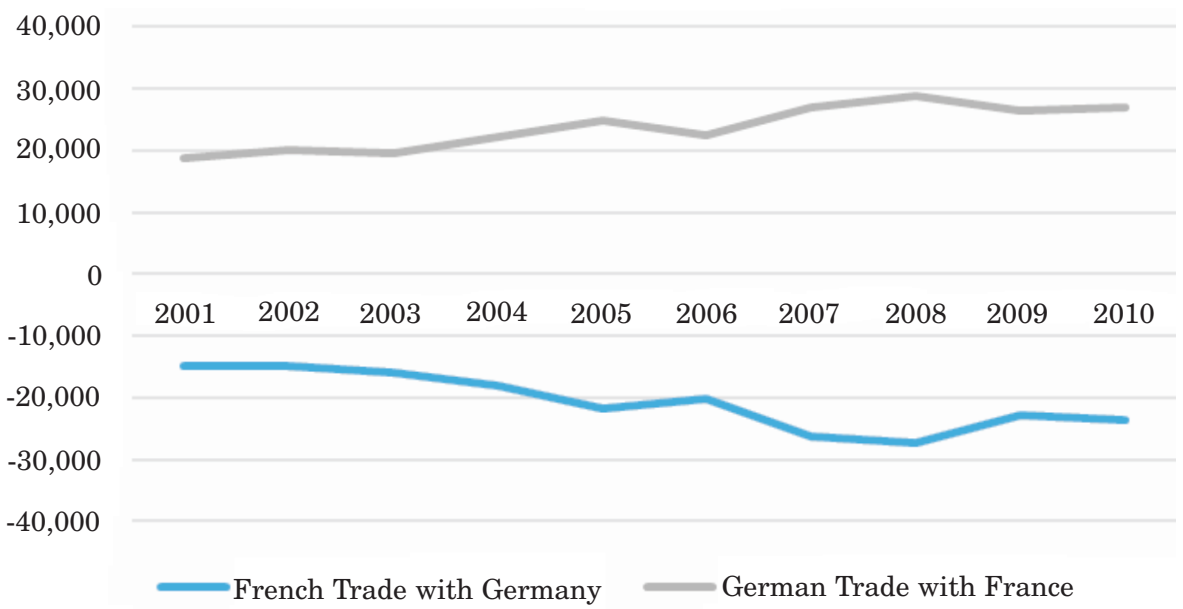

Fig. 1. Trade Balance France-Germany (Mio $€$ )

Source: Eurostat, European Commission. 
These policies based on bailouts in return to fiscal consolidation programmes in Greece, Ireland, Portugal, Spain and Cyprus, were accompanied by the ECB's assistance. By extending its Emergency Liquidity Assistance (ELA), the ECB participated in the "secondary" bond market of EMU member countries since 2012 and fully engaged in quantitative easing since March 2015. However, as the recent turmoil indicates, these initiatives have not restored confidence in EU financial markets, prompting a review by the ECB of its accommodative monetary policies in March 2016.

The assessment of the two countries' alliance would suggest that the origins of the ongoing problems in EMU can be traced back towards the end of the second period (1957-1975) and in particular, on the problems between surplus and deficit countries in the IMF system. Germany's growing reluctance and frustration with USA pressures to carry the burden of adjustment in the IMF system, as the major surplus country alongside Japan, via the appreciation of the mark provided an additional external motive to successive German governments to further engage in European monetary integration. The same problem, as developed within the EMU, has led to "German Hegemony", as a reunified, economically powerful Germany, free from security concerns, has simply no incentive to share the adjustment costs of fiscal consolidation in the EU, by reducing its current account surpluses. There is a need therefore to create new mechanisms/institutions that could deal with different growth performances and variable debt ratios in the EMU member countries by committing and transferring resources to the countries in need. The creation of an EMU fiscal union is vital to that end (Gros 2010, Gros, MAYER 2010).

\section{Conclusion-Lessons for Today}

The Franco-German relations have suffered many drawbacks since the early post war period. However, the alliance has successfully paved the way to the realisation of many projects (Single Market, EMS, EMU). In trying to assess the evolution of the characteristics of the alliance and the impact that the two countries relations had in European monetary integration, four periods are, identified since the end of WWII and their key features evaluated. This has led to the post-2010 period. Since 2011, Germany has acquired a hegemonic status in EMU and EU due to its financial supremacy over other EMU countries and in particular France. The latter unable to restore competitiveness losses accumulated since 1999, has assumed a semi-symbolic role in the alliance.

As it is unlikely that France will restore these losses in the near future, it is legitimate to assume that the alliance, at present, exists only in words, but not 
at deeds. From an institutional point of view, the alliance's features today resemble those of the early-1970s, with divergent economic interests. The solution to this divergence was provided by the creation of the EMS in 1978. However, it took twelve years for the EMS to be, integrated in a new European Treaty at Maastricht in 1991/92. Currently, this time is simply not available. Security concerns and the immigration influx to EU countries present challenges that push EU to its institutional limits. There is an urgent need for the ESM or a modified version of it, to be embedded in a new European Treaty, paving effectively the way to European economic governance, via the creation of a fiscal union. Further, the ECB should re-design its policies, with a view of adopting flexible inflation targeting (ODENDAHL 2014, 2015). This would allow wage bargaining processes in all Euro-zone countries within an environment that allows for, at least, modest increases in nominal wages (SCHMITT-GROHÉ, URIBE 2013, BibOW 2015, GAFFEY 2015, MoDy 2015). This would complete the process initiated in December 1991. Agreement in Maastricht was reached as Germany sacrificed the Deutschmark and France accepted full ECB independence. However, agreement on new European Treaty involving European economic governance is not within reach, as long as Germany is not willing to compromise, at least in the short run, on the ECB's policies, and France does not accept strict fiscal policy rules as part of that governance. The other two alternatives include a continuous EU leadership gap, or the continuous split between EMU north and south, leading potentially to the disintegration of the EMU that could also jeopardise the viability of EU.

Translated by AuTHOR

Accepted for print 30.06.2016

\section{References}

AnDREws D.M. 1993. The global origins of the Maastricht Treaty on EMU. In: The State of the European Community, vol. 2. Eds. A.W. Cafruny, G.G. Rosenthal. Boulder, Lynne Rienner.

ARRowsmith J. 1996. Is EMU riding for a fall? Paper presented to the Research Seminar in Bradford University, 8th November.

Bank for International Settlements. 1952. Twenty-Second Annual Report, April 1, 1951 - March 31, 1952', Basle.

BaUn M.J. 1996. The Maastricht Treaty as high politics: Germany, France and European Integration. Political Science Quarterly, 110(4): 605-624.

Bini-Smaghi L., Padoa-Scioppa T., Papadia F. 1994. The Transition to EMU in the Maastricht Treaty. Essays in International Finance, 194, November 1994, International Finance Section, Princeton University.

Biвоw J. 2015. The euro's savior? Assessing the ECB's crisis management performance and potential for crisis resolution. Institut für Makroökonomie und Konjunkturforschung/Macroeconomic Policy Institute, Study 42, www.boeckler.de/pdf/p_imk_study_42_2015.pdf.

Совнам D. 1994. European Monetary Upheavals. Manchester University Press, Manchester.

Cole A. 2001. Franco-German Relations: Political Dynamics of the European Union. Pearson Education Ltd, England. 
Crafts N., Toniolo G. 1996. Economic Growth in Europe Since 1945. Centre for Economic Policy Research, Cambridge University Press.

CRAM L. 1997. Policy-making in the EU: conceptual lenses and the integration process. Routledge, London and New York.

CRAwFord M. 1996. Foreword by Lord Kingsdown "One Money for Europe? The Economics and Politics of EMU". Macmillan, London.

Dinan D. 1999. Ever Closer Union: An Introduction to European Integration. Macmillan Press Ltd, London.

DormaEl A.V. 1978. Bretton Woods: Birth of a Monetary System. The Macmillan Press, London.

Dyson K., Featherstone K. 1999. The Road to Maastricht: Negotiating Economic and Monetary Union. Oxford University Press, Oxford.

External and intra-EU trade: A statistical yearbook, Data 1958-2010. 2011. Eurostat, Statistical Books, European Commission, http://ec.europa.eu/eurostat/documents/3217494/5729733/KS-GI11-001-EN.PDF/9e06d19b-bdce-49e0-a766-65fbbfc78081 (access: 14.08.2016).

Eichengreen B., Wyplosz C. 2016. Minimal Conditions for the Survival of the Euro. Intereconomics, 51(1): 24-28.

Fratianni M., von Hagen J. 1990a. German Dominance in the EMS: the Empirical Evidence. Open Economic Review, 1: 67-87.

Fratianni M., von Hagen J. 1990b. Asymmetries and Realignments in the EMS. In: The European Monetary Systemin the 1990s. Eds. P. De Grauwe, L. Papademos. Longman for CEPS and the Bank of Greece, London.

GAFFEY C. 2015. Germany and Greece Losers in ECB's Quantitative Easing Plan. Newsweek, 15th March, http://europe.newsweek.com/germany-and-greece-losers-ecbs-quantitative-easing-plan313740 .

GARRetT G. 1993. The politics of Maastricht. Economics and Politics, 5(2): 105-123.

George S. 1996. Policy and Politics in European Union. Oxford University Press, New York.

Giavazzi F., Giovannini A. 1989. Exchange Rate Flexibility: The European Monetary System. Cambridge University Press, Cambridge.

GisCARD D'ESTAING V.G. 1994. The year 2000: the European currency's first birthday. In: 30 years of European Monetary Integration from the Werner Plan to EMU. Ed. A. Steincherr. Longman, London.

Goodman S.F. 1996. The European Union. Macmillan Press Ltd., London.

Grauwe P. De. 1990. The Cost of Disinflation and the European Monetary System. Open Economies Review, 1: 147-173.

Gros D. 2010. Adjustment difficulties in the GIPSY Club. CEPS Working Document, 326, Centre for European Policy Studies, Brussels.

Gros D., Mayer T. 2010. Towards a Euro(pean) Monetary Fund. CEPS policy Brief, 202, Centre for European Policy Studies, Brussels.

Gros D., Thygesen N. 1998. European Monetary Integration: From EMS to EMU. Longman, London.

Henning C.R. 1998. Currencies and Politics in the Unites States, Germany and Japan. Institute for International Economics, Washington.

Hildebrand K. 1989. German Foreign Policy from Bismarck to Adenauer: The limits of statecraft. Translated by L. Willmot. Unwin Hyman Ltd., London.

HIx S. 1999. The Political System of the European Union. Macmillan Press Ltd., London.

JABKo N. 1999. In the name of the Market: How the European Commission paved the way for monetary union. Journal of European Public Policy, 6: 475-495.

Mazzucelli C. 1997. France and Germany at Maastricht. Policies and Negotiations to Create the European Union. Garland, New York.

McCarthy P. 2001. France-Germany: In the Twenty-First Century. Palgrave Macmillan, London.

McNamara R.K. 1998. The Currency of Ideas: Monetary Policies in the European Union. Cornell University Press, New York.

Mody A. 2015. Clueless in Europe. Bloomberg: 19th Oct, www.bloombergview.com/articles/2015-1019/the-european-central-bank-needs-to-get-a-clue.

Molle W. 1997. The Economics of European Integration: Theory, Practice and Policy. Ashgate Publishing Ltd, Aldershot Hants, England. 
MoravcsiK A. 1998. The Choice for Europe: Social Purpose and State Power from Rome to Maastricht. Cornell University Press, New York.

OdEnDAHL C. 2014. The ECB is not the German central bank. Centre for European Reform: London, 2nd December, www.cer.org.uk/insights/ecb-not-german-central-bank.

ODENDAHL C. 2015. Quantitative easing alone will not ward off deflation. Centre for European Reform, London, 21st January, http:/www.cer.org.uk/insights/quantitative-easing-alone-will-not-warddeflation.

OverTurf F.S. 1997. Money and European Union. St Martin's Press, New York.

PadoA-Scioppa T. 1988. The European Monetary System: a long-term view. In: The European Monetary System. Eds. S. Giavazzi, S. Micossi, M. Miller. Banca d'Italia, Centro Interuniversitario di Studi Teorici per la Politica Economica.

Pelkmans J. 1997. European Integration; Methods and Economic Analysis. Longman, London.

Report on Economic and Monetary Union in the European Community. 1989. Delors Committee, Office for Publications of the European Communities, Luxemburg.

Schmitt-Grohé S., URIBe M. 2013. Downward Nominal Wage Rigidity and the Case for Temporary Inflation in the Eurozone. Journal of Economic Perspectives, 27(3): 193-211.

Serfaty S. 1968. France, De Gaulle, \&Europe: The Policy of the Fourth and Fifth Republics towards the Continent. John Hopkins Press, Baltimore.

Solomon R. 1982. The International Monetary System, 1945-1976: An Insiders'View. Harper \& Row, New York.

Spahn P.B. 1993. The Community Budget for an Economic and Monetary Union. Macmillan Press Ltd., London.

Syrrakos D. 2010. A Reassessment of the Werner Plan and the Delors Report. Why did they experience a different fate? Comparative Economic Studies, 52: 575-588.

Summer M.T., Zis G. 1982. European Monetary Union: Progress and Prospects. Macmillan Press Ltd., London.

Szasz A. 1999. The Road to European Monetary Union. Macmillan Press Ltd., London.

TEw B. 1988. The Evolution of the International Monetary System, 1944-1988. Fourth Edition. Hutchinson, London.

TRIFFIn R. 1961. Gold and the Dollar Crisis. Yale University Press, New Haven, Connecticut.

Tsoukalis L. 1996. The New European Economy Revisited. Oxford University Press, Oxford.

Ungerer H. 1997. A Concise History of European Monetary Integration: From EPU to EMU. Quorum Books, Westport.

Vanthoor W. 1996. European Monetary Union since 1848: A Political and Historical Analysis. Edward Elgar Editions, Cheltenham.

VERDUN A. 1999. The role of the Delors Committee in the creation of EMU: an epistemic community? Journal of European Public Policy, 6(2): 308-328.

Wallace H., Wallace W. 2000. Policy-Making in the European Union. Oxford University Press, Oxford.

Watson M.S.A. 1997. Aspects of European Monetary Integration: The Politics of Convergence. Macmillan Press Ltd., London.

WebBer D. 1999. The Franco-German Relationship in the European Union. Routledge, London.

Williams A.M. 1991. The European Community. Blackwell, Oxford.

YeAger L. 1965. International Monetary Relations: Theory, History and Policy. A Harper International Edition. 